OPEN ACCESS

Edited by:

Adriana Lucia Romero-Olivares, New Mexico State University,

United States

Reviewed by:

Sarah R. Kyker,

The Holden Arboretum, United States Anna Clocchiatti,

Netherlands Institute of Ecology

(NIOO-KNAW), Netherlands

*Correspondence:

Carla Cruz-Paredes

carla.cruz_paredes.4058@biol.lu.se

Specialty section:

This article was submitted to

Forest Soils,

a section of the journal

Frontiers in Forests and Global

Change

Received: 23 September 2021

Accepted: 12 November 2021

Published: 15 December 2021

Citation:

Cruz-Paredes $C$

Bang-Andreasen T, Christensen $S$,

Ekelund F, Frøslev TG, Jacobsen CS, Johansen JL, Mortensen LH, Rønn R

Vestergård $M$ and Kjøller R (2021)

Bacteria Respond Stronger Than

Fungi Across a Steep Wood

Ash-Driven pH Gradient.

Front. For. Glob. Change 4:781844.

doi: 10.3389/ffgc.2021.781844

\section{Bacteria Respond Stronger Than Fungi Across a Steep Wood Ash-Driven pH Gradient}

\author{
Carla Cruz-Paredes ${ }^{1 *}$, Toke Bang-Andreasen ${ }^{1,2}$, Søren Christensen ${ }^{1}$, \\ Flemming Ekelund ${ }^{1}$, Tobias G. Frøslev' ${ }^{1}$, Carsten Suhr Jacobsen ${ }^{2}$, \\ Jesper Liengaard Johansen ${ }^{1}$, Louise H. Mortensen ${ }^{1}$, Regin Rønn'1, Mette Vestergård1 \\ and Rasmus Kjøller ${ }^{1}$
}

\begin{abstract}
'Department of Biology, University of Copenhagen, Copenhagen, Denmark, ${ }^{2}$ Department of Environmental Science, Aarhus University, Roskilde, Denmark
\end{abstract}

Soil $\mathrm{pH}$ is probably the most important variable explaining bacterial richness and community composition locally as well as globally. In contrast, $\mathrm{pH}$ effects on fungi appear to be less pronounced, but also less studied. Here we analyze the community responses of bacteria and fungi in parallel over a local extreme $\mathrm{pH}$ gradient ranging from 4 to 8 . We established the $\mathrm{pH}$ gradient by applying strongly alkaline wood ash in dosages of $0,3,9,15,30$, and $90 \mathrm{t} \mathrm{ha}^{-1}$ to replicated plots in a Picea abies plantation and assessed bacterial and fungal community composition using high throughput amplicon sequencing 1 year after ash application. At the same time, the experiment investigated if returning wood ash to plantation forests pose any immediate threats for the microbial communities. Among the measured environmental parameters, $\mathrm{pH}$ was by far the major driver of the microbial communities, however, bacterial and fungal communities responded differently to the $\mathrm{pH}$ increment. Whereas both bacterial and fungal communities showed directional changes correlated with the wood ash-induced increase in $\mathrm{pH}$, the bacterial community displayed large changes at wood ash dosages of 9 and $15 \mathrm{t} \mathrm{ha}^{-1}$ while only higher dosages $\left(\geq 30 \mathrm{t} \mathrm{ha}^{-1}\right)$ significantly changed the fungal community. The results confirm that fungi are less sensitive to $\mathrm{pH}$ changes than bacteria but also that fertilizing plantation forests with wood ash, viewed through the lens of microbial community changes, is a safe management at standard dosages (typically $\left.3 \mathrm{tha}^{-1}\right)$.

Keywords: pH, wood ash, bacteria, fungi, soil, microbial communities

\section{INTRODUCTION}

Soil microorganisms as bacteria and fungi provide important ecosystem services as primary decomposers of organic matter (Bardgett, 2005), and as symbionts assisting plants with nutrient uptake (Whitman et al., 1998; Smith and Read, 2008). Abundance as well as taxonomic and functional diversity of the microbial community is thus pivotal for the production, stability and resilience of any plant-soil system (van Der Heijden et al., 2008). In order to understand thoroughly the impact of environmental changes or management practices on microbial communities, we 
must understand the effect of specific measurable parametric changes that the microbial cells need to cope with.

Soil pH is consistently recorded as one of the most influential factors affecting microbial communities (Lauber et al., 2009; Rousk et al., 2009, 2010). Bacterial richness responds to soil pH in a bell-shaped fashion, where richness is highest in soils with near-neutral $\mathrm{pH}$, and lowest in soils with $\mathrm{pH}$ higher than 8 or lower than 4.5 (Lauber et al., 2009). In addition, community composition is strongly determined by soil $\mathrm{pH}$ (Lauber et al., 2009; Rousk et al., 2010). The pH effects on bacteria have been reported in mesocosm laboratory studies (Bang-Andreasen et al., 2017; Cruz-Paredes et al., 2017b), field-scale studies (Rousk et al., 2010), and at continental- to global-scale studies (Fierer et al., 2009; Lauber et al., 2009; Delgado-Baquerizo et al., 2018). In contrast, $\mathrm{pH}$ effects on fungi are less pronounced, and the responses of fungal communities appear weaker than those of bacterial communities. However, the effect of $\mathrm{pH}$ on fungi is much less studied in comparison to effects on bacteria (Rousk et al., 2010; Leifheit et al., 2014; Tedersoo et al., 2014; CruzParedes et al., 2017b). Still, pH appears to be a significant determinant for fungal communities, but typically not as the most important driver (Tedersoo et al., 2014; Bahram et al., 2018). In a global-scale study (Tedersoo et al., 2014), soil pH was one of the most important predictors of fungal richness. Specific fungal strains typically have a wider $\mathrm{pH}$ optimum, often covering a range of 5-9 $\mathrm{pH}$ units without significant inhibition of growth (Rousk et al., 2010; Bahram et al., 2018).

Application of wood ash on forest soil has been proposed to prevent acidification and nutrient depletion (Jacobson, 2003), improve plant production (Cruz-Paredes et al., 2017a; Johansen et al., 2021), and to recycle waste product (Huotari et al., 2015). Wood ash increases soil pH (Fritze et al., 2000; Perkiömäki and Fritze, 2002) and contains nutrients, e.g., phosphorus, calcium, potassium and magnesium, along with heavy metals, e.g., cadmium, zinc, and copper (Knapp and Insam, 2011). Wood ash additions are most relevant in conifer plantation systems on relatively poor soil, where applications will partly mitigate nutrient imbalances caused by repeated harvest and counteract the natural acidification happening in forest soils (Knapp and Insam, 2011). Wood ash induces changes in the microbial community structure (Perkiömäki and Fritze, 2002; Björk et al., 2010; Cruz-Paredes et al., 2017b) similar to those induced by increasing pH (Rousk et al., 2011). Increases in microbial activity may also occur after wood ash addition (Bååth et al., 1995; Perkiömäki and Fritze, 2002; Zimmermann and Frey, 2002; Mahmood et al., 2003; Insam et al., 2009). Even though wood ash does not contain $\mathrm{N}$, the increased $\mathrm{pH}$ after application often leads to higher $\mathrm{N}$ availability because of increased mineralization of organically bound N (Vestergård et al., 2018; Mortensen et al., 2020; Johansen et al., 2021). Moreover, wood ash addition tends to shift microbial communities toward increased bacterial and reduced fungal dominance (Bååth et al., 1995; Perkiömäki and Fritze, 2002). Micro- and mesocosm experiments with increasing dosages of wood ash in forest soil showed that the soil bacterial community composition changed after wood ash application. Copiotrophic bacteria responded positively while oligotrophic and acidophilic bacteria declined (Bang-Andreasen et al., 2017).
Studies on the effects of wood ash on fungal communities are limited, most of them quantified changes in the concentration of

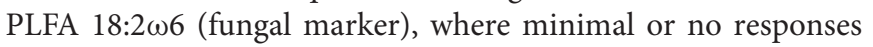
were recorded (Bååth et al., 1995; Perkiömäki and Fritze, 2002; Cruz-Paredes et al., 2017b). One microcosm experiment showed that fungi were less responsive than prokaryotic community to wood ash additions in forest and agricultural soil (BangAndreasen et al., 2020). For ectomycorrhizal fungal communities in particular, the addition of moderate levels of wood ash (3-7.5 $t$ $\mathrm{ha}^{-1}$ ) only seem to result in minor changes in the community composition despite a significant $\mathrm{pH}$ increment (Kjøller et al., 2017; Cruz-Paredes et al., 2019). A single study by Klavina et al. (2015), however, documented a very significant community shift between wood-ash-treated and control plots, but based on a rather high dose $\left(50 \mathrm{tha}^{-1}\right)$.

Bacterial and fungal communities have rarely been coanalyzed from the same field samples across a steep $\mathrm{pH}$ gradient. Here, we therefore analyzed the community responses of bacteria and fungi in parallel over a local wood-ash-induced $\mathrm{pH}$ gradient ranging from 4 to 8 . We applied strongly alkaline wood ash in dosages of $0,3,9,15,30$, and $90 \mathrm{tha}^{-1}$ to replicated plots in a Picea abies plantation. We hypothesized that:

(1) Both bacterial and fungal richness and diversity will increase with wood ash application as $\mathrm{pH}$ approaches 7, but diversity may decrease at the most extreme dosages when $\mathrm{pH}$ approaches 8.

(2) Wood ash application gradually changes the community structure of both bacteria and fungi at higher $\mathrm{pH}$ values, but bacterial communities respond stronger and at lower dosages than fungal communities do.

(3) With wood-ash-introduced $\mathrm{pH}$ increase and addition of nutrients, copiotrophic bacteria will thrive in expense of oligotrophic, and acidophilic bacterial groups will decrease with $\mathrm{pH}$ increments.

(4) Likewise, with $\mathrm{pH}$ increment we expect changes in the fungal community away from known acidophilic groups toward taxa thriving at higher $\mathrm{pH}$ and higher soil fertility.

\section{MATERIALS AND METHODS}

\section{Study Site}

The study site was a Norway spruce [Picea abies (L.) Karst.] plantation located in central Jutland, Denmark (N 56 ${ }^{\circ} 16.63$, E $\left.9^{\circ} 05.20\right), 51 \mathrm{~m}$ above sea level. The climate is temperate with a mean annual temperature of $8.4^{\circ} \mathrm{C}$ and a mean annual precipitation of $850 \mathrm{~mm}$. The experimental site is a secondgeneration plantation established in 1957 on former heathland with a well-developed podzolization formed on a well-drained, sandy glacial till. Mosses dominated the forest floor; in particular Hypnum jutlandicum, Dicranum scoparium and Pleurozium schreberi (Ethelberg-Findsen et al., 2021). The few understory plants are mainly Deschampsia flexuosa and Vaccinium vitisidaea. In a randomized split block design, we applied wood-ash 
in April 2014 to $2 \mathrm{~m} \times 2 \mathrm{~m}$ plots at six different dosages: 0, 3, 9, $15,30,90 \mathrm{tha}^{-1}$ with five replicate blocks $(n=5)$ with a total of 30 samples. We distributed the ash evenly over the soil surface, as a single addition. The ash came from wood chip fuel mixed ash from a combustion plant in Brande, Denmark, the particle size was less than $1 \mathrm{~mm}$, and the $\mathrm{pH}$ was 13 . Details on the elemental composition can be found under MA-9c in Maresca et al. (2017).

\section{Soil Sampling}

One year after application, in April 2015, we took three samples randomly with a $5 \mathrm{~cm}$ auger to a depth of $5 \mathrm{~cm}$ within each $2 \mathrm{~m} \times 2 \mathrm{~m}$ plot at least $30 \mathrm{~cm}$ from the edge. Samples spanned the organic horizon of the forest floor and included litter and moss when present. The samples were stored at $4^{\circ} \mathrm{C}$ and processed in the laboratory the day after collection. We pooled the three subsamples from each plot into one composite sample per plot, which we sieved $(5 \mathrm{~mm})$ and homogenized. Soil nutrients and $\mathrm{pH}$ of the homogenized composite samples were measured as in Vestergård et al. (2018). Soil for subsequent DNA extraction was frozen immediately after sieving and homogenizing.

\section{DNA Extraction, Library Preparation and Sequencing}

We extracted DNA from $3 \mathrm{~g}$ of frozen soil with the PowerMax Soil ${ }^{\circledR}$ kit (MoBIO, Carlsbad, United States). For amplifying the prokaryotic community, dual-labeled primers $515 \mathrm{f}$ and 806r (Caporaso et al., 2012) targeting the V4 region of the 16S rRNA gene were used. For amplifying the fungal communities, a fragment of rDNA (ITS2) was amplified using dual-labeled primers gITS7 and ITS4 (White et al., 1990; Ihrmark et al., 2012). The master mix for both bacterial and fungal amplification consisted of $0.3 \mu \mathrm{l}$ of PCR BIO HIFI Polymerase (PCR Biosystems Ltd., London, United Kingdom), $6 \mu \mathrm{l}$ of PCR BIO reaction buffer (PCR Biosystems Ltd., London, United Kingdom), $3 \mu \mathrm{l}$ of BSA, $0.6 \mu \mathrm{l}$ of dNTP $(10 \mathrm{mM})$, $15.6 \mu \mathrm{l}$ of dd $\mathrm{H}_{2} \mathrm{O}, 3 \mu \mathrm{l}$ of the primer mix and $1.5 \mu \mathrm{l}$ of DNA template. We made three independent PCR amplifications for each DNA sample. For bacteria, PCR conditions included $1 \mathrm{~min}$ denaturation at $95^{\circ} \mathrm{C} ; 30$ cycles of $15 \mathrm{~s}$ denaturation at $95^{\circ} \mathrm{C}$, $20 \mathrm{~s}$ annealing at $50^{\circ} \mathrm{C}$ and $20 \mathrm{~s}$ elongation at $72^{\circ} \mathrm{C}$; and a 5 min final elongation step. For fungi, PCR conditions were the same as for bacteria except that the annealing temperature was $56^{\circ} \mathrm{C}$. For each sample, we combined PCR products from the three independent PCRs (using the same tag combinations, in total 60 different sequencing tags were used) and purified using Agencourt AMPure XP beads (Beckman Coulter, Indianapolis, United States) according to the manufacturer's protocol. DNA concentrations were measured using Qubit (Thermo Fisher Scientific, Massachusetts, United States) and samples were mixed in equimolar concentrations to a total of $1,000 \mathrm{ng}$ of DNA for one adapter ligation reaction. Ligation of adapters was done using TruSeq DNA PCR-free LT Sample Preparation Kit (Illumina, San Diego, CA, United States). Sequencing was performed on the MiSeq (Illumina) platform using 250 bp paired-end and spiked with $30 \%$ PhiX DNA, bacteria and fungi were analyzed in separate runs. All the sequences were deposited in the Electronic Research
Data Archive (ERDA) at the University of Copenhagen (see section "Data Availability Statement").

\section{Molecular Characterization of the Bacterial and Fungal Communities}

Demultiplexing of samples, including removal of primers, tags and adapter remnants, was carried out with a custom script based on cutadapt (Martin, 2011). OTU tables for both bacteria and fungi were constructed, using the general approach of Frøslev et al. (2017) by initial processing with DADA2 (Callahan et al., 2016) to identify exact amplicon sequence variants (ASV). For the fungi, this was then followed by ITS extraction with ITSx (Bengtsson-Palme et al., 2013) and subsequent clustering with VSEARCH (Rognes et al., 2016) at 98.5\%-the consensus clustering level used to delimit species hypotheses ( $\mathrm{SHs}$ ) in the UNITE database (Kõljalg et al., 2005). Subsequently, a postclustering curation using LULU was done (Frøslev et al., 2017). Taxonomic assignment of the fungal OTUs was done using the 2017 UNITE general FASTA release ${ }^{1}$. We used 98, 90, 85, 80, 75, and $70 \%$ sequence identity for assigning OTUs to species, genus, family, order, or class and kingdom, respectively. Additionally, fungal guilds were determined using FUNGuild (Nguyen et al., 2016), and exploration types for ectomycorrhizal fungi based on the fungal traits database 1.2_ver_16Dec_2020 (Põlme et al., 2021). For the bacterial data, we used the unclustered ASVs from DADA2 as OTUs in following analyses, following taxonomic annotation using the RDP classifier against the Greengenes reference database v13.8. Singleton OTUs were removed.

\section{Statistical Analysis}

Richness (number of observed OTUs) and diversity (Shannon diversity) were calculated based on a rarified number of sequences per sample (limit set from the sample with the lowest number of sequences 1,668 for bacteria and 3,002 for fungi), using the vegan package (Oksanen et al., 2015) in R ( $\mathrm{R}$ Core Team, 2020). Regression analyses were conducted between wood ash addition and bacterial and fungal richness and diversity using the R function $I m$. Data that were non-normal (as per ShapiroWilk test), were log-transformed prior to statistical analyses. Data was also checked for homogeneity of variances (as per Bartlett's test). Non-metric multidimensional scaling (NMDS) ordination analyses were performed with Bray-Curtis dissimilarity matrices originating from bacterial and fungal OTU tables with relative abundance data. The vectors of wood ash, $\mathrm{pH}$, and inorganic $\mathrm{N}$ and $\mathrm{P}$ were fitted onto ordination space (Bray-Curtis NMDS) to detect possible associations between patterns of community structure and these variables using the envfit function from the vegan package (Oksanen et al., 2015). We used one-way ANOVA to test the effect of wood ash dosage on the BrayCurtis dissimilarities between microbial communities in wood ash treated and control soil. Initially we tested for any block effects, but since there were none, these were omitted from the final models. In the case of significant differences, we tested pairwise differences with a Tukey's HSD multiple comparison test. Moreover, significant differences between bacterial and

\footnotetext{
${ }^{1}$ http://dx.doi.org/10.15156/BIO/587475
} 
TABLE 1 | Bacterial and fungal OTU richness and diversity (Shannon index) in the different wood ash additions.

\begin{tabular}{lcccc}
\hline & $\begin{array}{c}\text { Bacterial } \\
\text { richness }\end{array}$ & $\begin{array}{c}\text { Bacterial } \\
\text { diversity }\end{array}$ & $\begin{array}{c}\text { Fungal } \\
\text { richness }\end{array}$ & $\begin{array}{c}\text { Fungal } \\
\text { diversity }\end{array}$ \\
\hline Wood ash additions & & & & \\
$0 \mathrm{t} \mathrm{ha}^{-1}$ & $153 \pm 38$ & $4.4 \pm 0.2$ & $106 \pm 7$ & $3.3 \pm 0.1$ \\
$3 \mathrm{t} \mathrm{ha}^{-1}$ & $219 \pm 94$ & $4.3 \pm 0.5$ & $124 \pm 13$ & $3.2 \pm 0.1$ \\
$9 \mathrm{t} \mathrm{ha}^{-1}$ & $204 \pm 78$ & $4.3 \pm 0.3$ & $141 \pm 12$ & $3.3 \pm 0.1$ \\
$15 \mathrm{t} \mathrm{ha}^{-1}$ & $212 \pm 66$ & $4.5 \pm 0.3$ & $136 \pm 25$ & $3.4 \pm 0.2$ \\
$30 \mathrm{t} \mathrm{ha}^{-1}$ & $154 \pm 39$ & $4.2 \pm 0.2$ & $190 \pm 29$ & $3.5 \pm 0.1$ \\
$90 \mathrm{t} \mathrm{ha}^{-1}$ & $228 \pm 76$ & $4.4 \pm 0.4$ & $158 \pm 19$ & $3.6 \pm 0.2$ \\
\hline
\end{tabular}

Values refer to mean values \pm standard error.

fungal community composition were tested for the different wood ash dosages also using PERMANOVA on a Wisconsin standardized Bray-Curtis dissimilarity matrix with the $\mathrm{R}$ function adonis from the vegan package (Oksanen et al., 2015) and pairwise PERMANOVA was used to test pairwise differences using the function pairwise adonis (Martinez Arbizu, 2020). Furthermore, correlations of microbial richness, diversity, and wood ash treatments with $\mathrm{pH}$ and inorganic $\mathrm{N}$ and $\mathrm{P}$ were evaluated using Pearson's correlations and p-values were the significance level of $t$-test. All statistical analyses were done in $\mathrm{R}$ version 4.0.3 (R Core Team, 2020).

\section{RESULTS}

\section{Effects of Wood Ash Treatments on pH and Inorganic $\mathbf{N}$ and $\mathbf{P}$}

Wood ash addition to the forest soil increased soil $\mathrm{pH}$ significantly from 3.8 in control plots, to 7.7 in plots treated with $90 \mathrm{t} \mathrm{ha}^{-1}$ of wood ash (see Vestergård et al., 2018 for details). Besides soil $\mathrm{pH}$, concentrations of $\mathrm{NH}_{4}-\mathrm{N}, \mathrm{NO}_{3}-\mathrm{N}$ and $\mathrm{PO}_{4}-\mathrm{P}$ increased significantly with wood ash additions, from 1.46 to 18.97 , from 0.14 to 5.95 and from 3.89 to $223.80 \mu \mathrm{g} \mathrm{cm}^{-3}$, respectively (Vestergård et al., 2018). Wood ash amendment and soil $\mathrm{pH}$ significantly correlated with the increasing concentrations of $\mathrm{NH}_{4}, \mathrm{NO}_{3}, \mathrm{PO}_{4}$ (data not shown). The strongest correlation was found between wood ash and $\mathrm{pH}$ (Pearson's, $r=0.82, p<0.001$ ).

\section{Richness and Diversity of Bacterial and Fungal Communities}

We evaluated richness as observed number of OTUs, and diversity as the Shannon index. Bacterial richness (number of OTUs) varied between 153 and 228 (Table 1), but neither bacterial richness nor diversity differed significantly between treatments or correlated with any of the abiotic parameters above. Fungal richness increased from 106 at 0 to 158 at $90 \mathrm{t}$ $\mathrm{ha}^{-1}$, however, differences were not significant. Fungal diversity correlated positively with both wood ash additions and $\mathrm{pH}$, as well as ammonium, nitrate and phosphate concentrations (Pearson's, $r=0.41, \quad 0.43, \quad 0.45, \quad 0.38, \quad 0.43$, respectively, $0.01<p<0.05)$.

\section{Composition of Bacterial and Fungal Communities}

As evident from the NMDS ordinations (Figure 1) there was a strong influence of soil $\mathrm{pH}$ (colors) on the composition of the bacterial and fungal communities across the gradient of increasing wood ash (shapes). $\mathrm{pH}$ aligned strongly with the first axis of the plot similarly to wood ash addition (Figures 1A,C). NDMS axis 1 correlated strongest with $\mathrm{pH}$ (Pearson's, $r=-0.9$, $p<0.001$ ) followed by wood ash, $\mathrm{NH}_{4}, \mathrm{PO}_{4}$, and $\mathrm{NO}_{3}$ (Pearson's, $r=-0.71,-0.71,-0.69$, and -0.68 , respectively, $p<0.001)$.

Likewise, the envfit analysis showed that $\mathrm{pH}$ correlated the best with the NMDS projections followed by the wood ash treatment and the nitrogen and phosphorus measurements (Table 2). The PERMANOVA test showed that wood ash dosage significantly affected both bacterial ( $p$ seudo- $F_{5,24}=2.1$, $\left.R^{2}=0.30, p=0.001\right)$ and fungal (pseudo- $F_{5,24}=1.3, R^{2}=0.22$, $p=0.008)$ communities.

We plotted the average Bray-Curtis dissimilarities of the two microbial communities comparing control plots with plots treated with increasing amounts of wood ash (Figures 1B,D). For both communities, the average distance between the five replicated control plots was lower than 0.7. For bacterial communities, the rate of change was larger than for fungal communities and dissimilarity from control was significant from $9 \mathrm{t} \mathrm{ha}^{-1}(\mathrm{pH} \approx 5)$ (Tukey test $\left.p<0.001\right)$ (Figure $\left.1 \mathbf{B}\right)$. Furthermore, another "breakpoint" occurred between 15 and $30 \mathrm{tha}^{-1}$ (pH between 5.9 and 6.8) and dissimilarity increased to over 0.9 for the $90 \mathrm{t} \mathrm{ha}^{-1}(\mathrm{pH} \approx 7.7)$ compared with control (Tukey test $p<0.001$ ). The fungal communities did not differ significantly from the control at dosages below $30 \mathrm{t}$ $\mathrm{ha}^{-1}$ (Figure 1D) (Tukey test $p<0.001$ for 30 and $90 \mathrm{t}$ $\mathrm{ha}^{-1}$ ) and the overall difference never exceeded 0.8. Likewise, the pairwise PERMANOVA showed that bacterial communities from wood ash treated plots, differed significantly from the control plots at lower dosages than the fungal communities $\operatorname{did}$ (Table 3).

\section{Taxonomic Composition of Bacterial and Fungal Communities}

We plotted the relative abundances of the ten most abundant bacterial phyla in the plots treated with increasing dosages of wood ash (Figure 2A). In control plots, Acidobacteria had the highest relative abundance (32\%), however, with increasing dosages of wood ash, the relative abundance decreased significantly (one-way ANOVA, $F_{5,24}=12.8, p<0.001$ ). In contrast, the relative abundance of Bacteriodetes increased significantly $\left(F_{5,24}=12.7, p<0.001\right)$ with increasing wood ash and reached a maximum $(36 \%)$ at $30 \mathrm{t} \mathrm{ha}^{-1}(\mathrm{pH} \approx 6.8)$. The relative abundance of Firmicutes also increased significantly $\left(F_{5,24}=6.0, p<0.001\right)$ at the highest wood ash addition $(\mathrm{pH} \approx$ 7.7). Other phyla like Chloroflexi had significant $\left(F_{5,24}=3.3\right.$, $p=0.02)$ higher relative abundance at an intermediate addition (30 $\mathrm{tha}^{-1}, \mathrm{pH} \approx 6.8$ ).

Likewise, we compared the relative abundance of the most abundant fungal genera across the $\mathrm{pH}$ gradient (Figure 2B). As for bacteria, the results indicate three different responses to the 

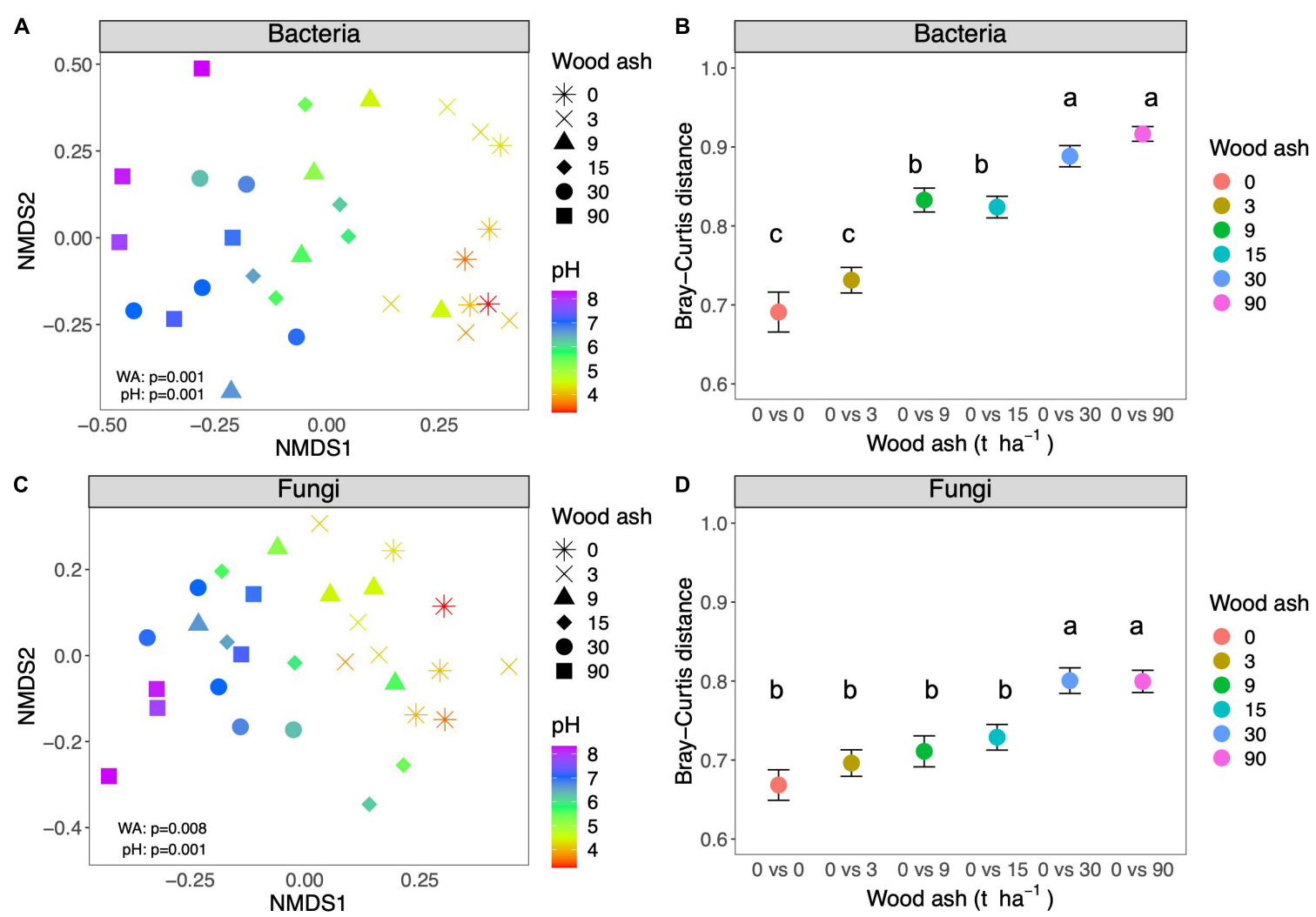

FIGURE 1 | NMDS plot of Bray-Curtis dissimilarities between $\mathbf{( A )}$ bacterial communities (stress = 0.13 ) and $(\mathbf{C})$ fungal communities (stress = 0.19$)$ from samples from the different wood ash treatments (different shapes). Soil pH measured in the different samples is also indicated with a color scale. Average Bray-Curtis dissimilarities of (B) bacterial and (D) fungal communities of untreated plots (no wood ash addition) compared to plots treated with increasing wood ash additions. Different letters denote significant difference $(p<0.05)$ obtained from Tukey post hoc tests.

increasing wood ash $/ \mathrm{pH}$ increment. Tylospora and Piloderma are examples of genera decreasing in relative abundance from 23 and $8 \%$ in the control treatment to 6 and $0 \%$, respectively, at the highest dosage $(\mathrm{pH} \approx 7.7)$ but differences were not significant. In contrast, genera as Hebeloma and Didymella were not detected in control plots but increased significantly at higher wood ash doses $\left(F_{5,24}=2.0, p=0.04\right.$ and $F_{5,24}=3.0, p=0.03$, respectively). Finally, Amphinema and Russula were examples of bell-shaped responses where abundances peaked at intermediate wood ash additions but these were not significant.

Additionally, we partitioned the fungal community into trophic groups and functional guilds (Figure 2C). "Ectomycorrhizal" was the most abundant guild in all treatments, but the relative abundance of this guild decreased slightly with increasing wood ash additions. Other guilds, such as "Pathogen" and "Endophyte" increased significantly $\left(F_{5,24}=3.0, p=0.003\right.$ and $F_{5,24}=3.0, p=0.01$, respectively) with wood ash additions. Note, however, that the increase in "Pathogen" mimics the increase of the single species Didymella aurea. Finally, we further partitioned "Ectomycorrhizal" into exploration types (Figure 2D); again, the most obvious changes, like the decrease of "medium-distance_fringe," mimics the changes in Cortinarius across the treatments.
TABLE 2 | Results of envfit analyses.

\begin{tabular}{lcc}
\hline & Bacterial communities & Fungal communities \\
\hline Explanatory variable & & \\
$\mathrm{pH}$ & $0.88^{\star \star \star}$ & $0.86^{\star \star \star}$ \\
Wood ash $\left(\mathrm{t} \mathrm{ha}^{-1}\right)$ & $0.73^{\star \star \star}$ & $0.52^{\star \star \star}$ \\
$\mathrm{NH}_{4}\left(\mu \mathrm{g} \mathrm{cm}^{-3}\right)$ & $0.51^{\star \star \star}$ & $0.29^{\star}$ \\
$\mathrm{NO}_{3}\left(\mu \mathrm{g} \mathrm{cm}^{-3}\right)$ & $0.47^{\star \star \star}$ & $0.34^{\star \star}$ \\
$\mathrm{PO} 4\left(\mu \mathrm{g} \mathrm{cm}^{-3}\right)$ & $0.48^{\star \star \star}$ & $0.26^{\star}$ \\
\hline
\end{tabular}

The envfit analysis tests for significant correlation of environmental parameters to the NMDS projections of community dissimilarities between samples (Bray-Curtis), all parameters separately.

Values refer to squared correlation coefficient $\left(r^{2}\right)$.

*refer to significance level ${ }^{*}$ is $0.01<p<0.05,{ }^{* *}$ is $0.001<p<0.01$, and ${ }^{* * *}$ is $p<0.001)$.

\section{DISCUSSION}

In this study, we applied increasing dosages of wood ash to an acid forest soil which resulted in a steep local $\mathrm{pH}$ gradient. This allowed us to map in parallel the dose-response functions of fungi and bacteria to $\mathrm{pH}$. In line with previous studies, we found that while both bacterial and fungal communities responded significantly to $\mathrm{pH}$, bacteria were both more sensitive and 
TABLE 3 | Pairwise testing for significant difference in bacterial and fungal communities between increasing wood ash dosages.

\begin{tabular}{|c|c|c|c|c|c|}
\hline & $3 \mathrm{tha}^{-1}$ & $9 \mathrm{tha}^{-1}$ & $15 \mathrm{tha}^{-1}$ & $30 \mathrm{t} \mathrm{ha}^{-1}$ & $90 \mathrm{tha}^{-1}$ \\
\hline \multicolumn{6}{|c|}{ Bacterial communities } \\
\hline $0 \mathrm{tha}^{-1}$ & 0.10 & $0.21^{*}$ & $0.23^{\star \star}$ & $0.27^{\star \star}$ & $0.30^{\star \star}$ \\
\hline $3 \mathrm{tha}^{-1}$ & & 0.13 & 0.16 & $0.21^{\star \star}$ & $0.23^{\star \star}$ \\
\hline $9 \mathrm{tha}^{-1}$ & & & 0.09 & 0.13 & $0.17^{\star}$ \\
\hline 15 t ha $^{-1}$ & & & & 0.11 & $0.16^{*}$ \\
\hline $30 \mathrm{tha}^{-1}$ & & & & & 0.11 \\
\hline \multicolumn{6}{|c|}{ Fungal communities } \\
\hline $0 \mathrm{tha}^{-1}$ & 0.08 & 0.13 & $0.16^{\star}$ & $0.18^{\star}$ & $0.22^{\star \star}$ \\
\hline $3 \mathrm{tha}^{-1}$ & & 0.10 & 0.12 & 0.14 & $0.17^{*}$ \\
\hline $9 \mathrm{tha}^{-1}$ & & & 0.14 & 0.12 & 0.16 \\
\hline $15 \mathrm{t} \mathrm{ha}^{-1}$ & & & & 0.12 & 0.15 \\
\hline $30 \mathrm{t} \mathrm{ha}^{-1}$ & & & & & 0.09 \\
\hline
\end{tabular}

Statistical test used: PERMANOVA.

Values refer to $R^{2}$-values.

*refer to significance level ${ }^{*}$ is $0.01<p<0.05,{ }^{* *}$ is $0.001<p<0.01$, and ${ }^{* * *}$ is $p<0.001)$.

responded stronger to the $\mathrm{pH}$ increase than fungi (Rousk et al., 2010; Cruz-Paredes et al., 2017b; Bang-Andreasen et al., 2020).

\section{Bacterial and Fungal Richness}

We found no effects of wood ash or increasing $\mathrm{pH}$ on bacterial richness or diversity, while both fungal richness and diversity increased with higher wood ash dosages, and thus, increasing $\mathrm{pH}$. Our hypothesis (1) that bacterial and fungal diversity would increase with increased $\mathrm{pH}$ was only partly supported. Furthermore, we did not see any negative effects on diversity at the highest $\mathrm{pH}$ levels, as we expected. In a global-scale study (Tedersoo et al., 2014), soil pH was one of the most important predictors of fungal OTU richness. This was similar to our study where fungal richness was positively correlated with soil pH. However, at the local scale, Rousk et al. (2010) found that in an arable soil both bacterial and fungal richness increased with $\mathrm{pH}$ ( $\mathrm{pH} 4.0-8.3$ ), but for fungi, this response was only marginal. In a microcosm study where wood ash was added in increasing dosages, an opposite trend was found, since bacterial richness and diversity decreased with increasing wood ash additions (Bang-Andreasen et al., 2017). However, it is important to mention that the doses applied were higher (up to $167 \mathrm{t} \mathrm{ha}^{-1}$ ) than in the present study, and that the response was evaluated almost immediately after the additions. In our study, there were no negative effects on either fungal or bacterial richness with application of wood ash, which once again demonstrate how resilient microbial populations are to perturbations (Bardgett and Caruso, 2020).

\section{Community Composition}

In accordance with our hypothesis (2), community composition of both bacteria and fungi changed with increasing amounts of wood ash. Dosages of $9 \mathrm{t} \mathrm{ha}^{-1}(\mathrm{pH} \approx 5)$ of wood ash significantly changed bacterial communities, while significant fungal community changes were only observed at higher dosages $\left(30 \mathrm{t} \mathrm{ha}^{-1}\right)(\mathrm{pH} \approx 6.8)$ in line with our expectations. Among the measured environmental parameters, $\mathrm{pH}$ was by far the major driver of the microbial communities, and we showed how the relative abundance of certain bacterial phyla and fungal genera changed with soil $\mathrm{pH}$. Interestingly, we have previously shown that microbial biomass markers (ergosterol, fungal and bacterial PLFAs) did not change systematically with wood ash additions in samples from the same plots as used in this study (Cruz-Paredes et al., 2017b). The relative changes in abundances seen in this study therefore putatively indicate also changes in living biomass of those same groups.

Changes in community composition of bacteria and fungi due to wood ash, correlated with soil $\mathrm{pH}$ and concentrations of inorganic N. As mentioned above, bacterial taxa have much more narrow $\mathrm{pH}$ optima and a deviation of only $1.5 \mathrm{pH}$ units can reduce the growth by $50 \%$ (Fernández-Calviño and Bååth, 2010). Hence, even relatively small $\mathrm{pH}$ changes can change competitive balances between bacterial populations and lead to rapid replacement of populations with different $\mathrm{pH}$ optima (Booth, 1985). In contrast, fungal taxa have wider $\mathrm{pH}$ optima with the growth of filamentous fungi being unaffected even when pH changes 5-9 units (Wheeler et al., 1991; Nevarez et al., 2009; Strickland and Rousk, 2010). Furthermore, as pH strongly influences proton-driving force across the cell membrane, this may also explain why bacteria in general respond stronger to $\mathrm{pH}$ changes than fungi. Soil bacteria are completely dependent on their local water-filled soil pore environment on $\mu \mathrm{m}$ scale (Bardgett, 2005) while fungi have the possibility to bridge through both water-filled and air-filled spaces in the soil, though nutrient uptake can only take place in the water film (Moore et al., 2011). In addition, fungi have the option to seek out many soil compartments in three dimensions, with their extension of mycelia. This may be particular relevant when a perturbation as application of wood ash is placed on top of the soil.

\section{Bacterial Community Composition}

The changes in the relative abundances of bacterial phyla with increasing wood ash are consistent with responses to $\mathrm{pH}$ increase (Lauber et al., 2009; Rousk et al., 2010). Similar to our results, Lauber et al. (2009) found that Acidobacteria had the highest relative abundance at lower $\mathrm{pH}$. In addition, the relative abundance of Bacteriodetes increased with increasing $\mathrm{pH}$. Besides increasing soil $\mathrm{pH}$, wood ash adds nutrients to the soil. In line with our hypothesis (3), some of the bacterial taxa such as Bacteriodetes and Firmicutes, which increased in relative abundance with wood ash, comprises copiotrophic bacteria that could benefit from increasing nutrient availability (Fierer et al., 2007, 2012). On the contrary, oligotrophic groups such as Acidobacteria (Ho et al., 2017), decrease with wood ash additions, as shown in previous studies (Bang-Andreasen et al., 2017, 2020, 2021).

\section{Fungal Community Composition}

Previously, few studies have investigated how wood ash addition affect the total fungal community composition. Most previous studies have focused on ectomycorrhizal fungal communities (Taylor and Finlay, 2003; Klavina et al., 2015; Cruz-Paredes et al., 2019). Similar to our findings, a meta-analysis on the 

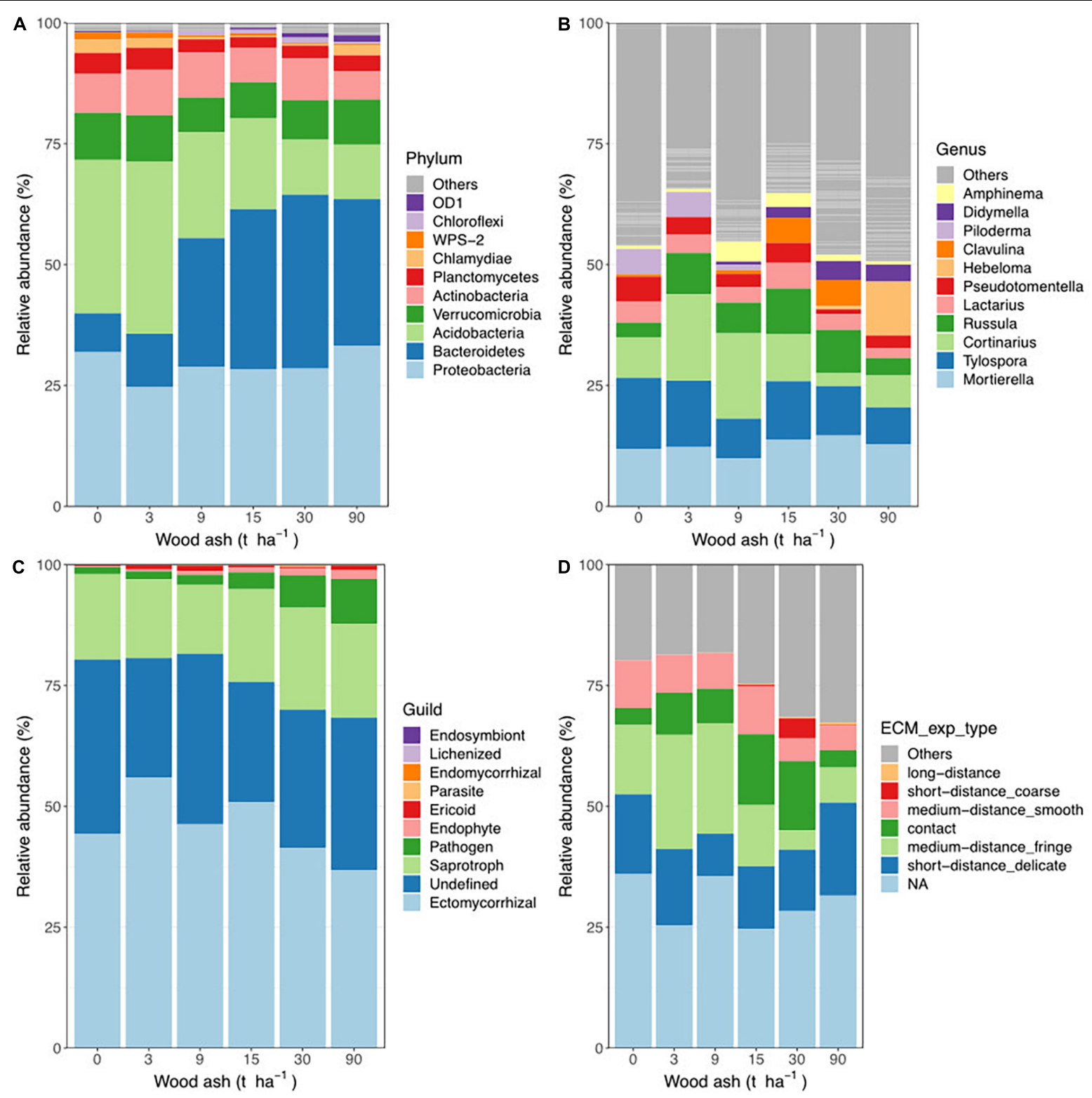

FIGURE 2 | Relative abundance of (A) most abundant bacterial phyla, (B) most abundant fungal genera, (C) different fungal guilds and (D) ECM exploration types across wood ash treatments.

effects of liming and wood ash additions on ectomycorrhizal fungi showed that the relative abundance of Tylospora fibrillosa decreased in treated plots compared to control (Kjøller et al., 2017). The meta-analysis also showed that Piloderma croceum decreased in relative abundance in treated plots (Kjøller et al., 2017), while we found that this genus was completely absent at the highest additions. On the contrary, the genus Hebeloma was not present in control plots, but the relative abundance increased with wood ash addition. This is in line with previous observations in peat soils amended with wood ash (Klavina et al., 2015; Klaviņa et al., 2016). Similarly, the genus Didymella was absent in control plots and increased in relative abundance with increasing wood ash levels. Tylospora, Piloderma and Cortinarius are known acidophilic fungi while at least some Heboloma are nitrophilic (Kjøller et al., 2017; Lilleskov et al., 2019) therefore decreases of acidophilic and increases of nitrophilic groups are in line with our last hypothesis (4).

Finally, we also looked at how wood ash additions affected the relative abundance of the different fungal guilds. In control plots, the most abundant guild was the "Ectomycorrhizal" (45\%) but with increasing wood ash additions, the relative abundance of this guild was reduced to $34 \%$ in $90 \mathrm{t} \mathrm{ha}^{-1}(\mathrm{pH} \approx 7.7)$. Still "Ectomycorrhizal" was the most abundant guild in all treatments (not taking the non-assigned into account). We also found that the relative abundance of the "Saprotroph," "Pathogen," and "Endophyte" guilds tended to increase with wood ash additions. 
The tendency of the relative abundance of saprotrophic fungi to increase on the expense of ectomycorrhizal fungi fits well with the increasing amounts of $\mathrm{NH}_{4}$ and $\mathrm{NO}_{3}$ with higher wood ash dosages observed (Vestergård et al., 2018). With improved availability of nutrients such as ammonia, nitrate and phosphorus the need for the plant to invest in their mycorrhizal partner likely decreases (Kiers et al., 2011).

\section{CONCLUSION}

We applied increasing amounts of wood ash to an acidic forest floor and thereby successfully manipulated the soil $\mathrm{pH}$ from the ambient $\approx 4$ to $\approx 8$. This allowed us to model the responses of both fungal and bacterial richness as well as the communities and specific taxa within these groups. Community composition changed significantly for both microbial groups with $\mathrm{pH}$. As expected, bacteria were more sensitive to $\mathrm{pH}$ changes, responding at lower dosages, and changing more from the start position than fungi. Despite the community changes, richness was either constant (bacteria) or increased with $\mathrm{pH}$ (fungi) which indicates that the microbial communities remained diverse also with relation to function (as shown for functional groups of fungi). $\mathrm{pH}$ was by far the best descriptor for the observed microbial community changes, better than the wood ash dosages or the $\mathrm{PO}_{4}$ added with the wood ash. Still, we did not measure all possible elements or water-soluble ions and acknowledge that other unmeasured elements applied with the wood ash may have contributed to the changes observed. Finally, the lack of effects at the low (realistic) to even medium high dosages after 1 year of wood ash applications, allows us to conclude that the use of wood ash as a liming and fertilization treatment in forestry does not pose harmful effects on the investigated variables.

\section{REFERENCES}

Bååth, E., Frostegård, Å, Pennanen, T., and Fritze, H. (1995). Microbial community structure and $\mathrm{pH}$ response in relation to soil organic matter quality in woodash fertilized, clear-cut or burned coniferous forest soils. Soil Biol. Biochem. 21, 229-240. doi: 10.1016/0038-0717(94)00140-v

Bahram, M., Hildebrand, F., Forslund, S. K., Anderson, J. L., Soudzilovskaia, N. A., Bodegom, P. M., et al. (2018). Structure and function of the global topsoil microbiome. Nature 560, 233-237. doi: 10.1038/s41586-018-0386-6

Bang-Andreasen, T., Anwar, M. Z., Lanzén, A., Kjøller, R., Rønn, R., Ekelund, F., et al. (2020). Total RNA sequencing reveals multilevel microbial community changes and functional responses to wood ash application in agricultural and forest soil. FEMS Microbiol. Ecol. 96, 1-13. doi: 10.1093/femsec/fiaa016

Bang-Andreasen, T., Nielsen, J. T., Voriskova, J., Heise, J., Rønn, R., Kjøller, R., et al. (2017). Wood ash induced $\mathrm{pH}$ changes strongly affect soil bacterial numbers and community composition. Front. Microbiol. 8:1-14. doi: 10.3389/fmicb. 2017.01400

Bang-Andreasen, T., Peltre, M., Ellegaard-Jensen, L., Hansen, L. H., Ingerslev, M., Rønn, R., et al. (2021). Application of wood ash leads to strong vertical gradients in soil $\mathrm{pH}$ changing prokaryotic community structure in forest top soil. Sci. Rep. 11, 1-10. doi: 10.1038/s41598-020-80732-0

Bardgett, R. D. (2005). The Biology of Soil. Oxford: Oxford University Press.

Bardgett, R. D., and Caruso, T. (2020). Soil microbial community responses to climate extremes: resistance, resilience and transitions to alternative states. Philos. Trans. R. Soc. B Biol. Sci. 375:20190112. doi: 10.1098/rstb.2019.0112

\section{DATA AVAILABILITY STATEMENT}

The datasets presented in this study can be found in online repositories. The names of the repository/repositories and accession number(s) can be found below: https://erda.ku.dk/ archives/e990eedc9f4e7ad453010efc81b31f70/published-archive. html.

\section{AUTHOR CONTRIBUTIONS}

CC-P and TB-A did the laboratory work. TB-A and TF performed the bioinformatic analysis and wrote sections of the manuscript. CC-P performed the statistical analysis. CC-P and RK wrote the first draft of the manuscript. All authors contributed to the conception, design of the study, manuscript revision, established the field experiment, read, and approved the submitted version.

\section{FUNDING}

This work was supported by the "Center for Bioenergy Recycling - ASHBACK” project (www.ashback.dk), funded by the Danish Council for Strategic Research (Grant No. 060300587B).

\section{SUPPLEMENTARY MATERIAL}

The Supplementary Material for this article can be found online at: https://www.frontiersin.org/articles/10.3389/ffgc.2021. 781844/full\#supplementary-material

Bengtsson-Palme, J., Ryberg, M., Hartmann, M., Branco, S., Wang, Z., Godhe, A., et al. (2013). Improved software detection and extraction of ITS1 and ITS2 from ribosomal ITS sequences of fungi and other eukaryotes for analysis of environmental sequencing data. Methods Ecol. Evol. 4, 914-919.

Björk, R. G., Ernfors, M., Sikström, U., Nilsson, M. B., Andersson, M. X., Rütting, T., et al. (2010). Contrasting effects of wood ash application on microbial community structure, biomass and processes in drained forested peatlands. FEMS Microbiol. Ecol. 73, 550-562. doi: 10.1111/j.1574-6941.2010.00911.x

Booth, I. R. (1985). Regulation of cytoplasmic pH in bacteria. Microbiol. Rev. 49, 359-378. doi: 10.1128/mmbr.49.4.359-378.1985

Callahan, B. J., Mcmurdie, P. J., Rosen, M. J., and Han, A. W. (2016). HHS Public Access. Nat. Methods 13, 581-583. doi: 10.1038/nmeth.3869.DADA2

Caporaso, J. G., Lauber, C. L., Walters, W. A., Berg-Lyons, D., Huntley, J., Fierer, N., et al. (2012). Ultra-high-throughput microbial community analysis on the Illumina HiSeq and MiSeq platforms. ISME J. 6, 1621-1624. doi: 10.1038/ismej. 2012.8

Cruz-Paredes, C., López-García, Á, Rubæk, G. H., Hovmand, M. F., Sørensen, P., and Kjøller, R. (2017a). Risk assessment of replacing conventional P fertilizers with biomass ash: residual effects on plant yield, nutrition, cadmium accumulation and mycorrhizal status. Sci. Total Environ. 575, 1168-1176. doi: 10.1016/j.scitotenv.2016.09.194

Cruz-Paredes, C., Wallander, H., Kjøller, R., and Rousk, J. (2017b). Using community trait-distributions to assign microbial responses to $\mathrm{pH}$ changes and $\mathrm{Cd}$ in forest soils treated with wood ash. Soil Biol. Biochem. 112, 153-164. doi: 10.1016/j.soilbio.2017.05.004 
Cruz-Paredes, C., Frøslev, T. G., Michelsen, A., Bang-Andreasen, T., Hansen, M., Ingerslev, M., et al. (2019). Wood ash application in a managed Norway spruce plantation did not affect ectomycorrhizal diversity or $\mathrm{N}$ retention capacity. Fungal Ecol. 39, 1-11. doi: 10.1016/j.funeco.2018.11.002

Delgado-Baquerizo, M., Oliverio, A. M., Brewer, T. E., Benavent-González, A., Eldridge, D. J., Bardgett, R. D., et al. (2018). A global atlas of the dominant bacteria found in soil. 325, 320-325. doi: 10.1126/science.aap9516

Ethelberg-Findsen, D., Rønn, R., and Ekelund, F. (2021). Wood ash application reduces bryophyte cover and changes species composition in a norway spruce (Picea abies) plantation. Forests 12, 1-14. doi: 10.3390/f12020178

Fernández-Calviño, D., and Bååth, E. (2010). Growth response of the bacterial community to $\mathrm{pH}$ in soils differing in pH. FEMS Microbiol. Ecol. 73, 149-156. doi: 10.1111/j.1574-6941.2010.00873.x

Fierer, N., Bradford, M. A., and Jackson, R. B. (2007). Toward an ecological classification of soil bacteria. Ecology 88, 1354-1364. doi: 10.1890/05-1839

Fierer, N., Lauber, C. L., Ramirez, K. S., Zaneveld, J., Bradford, M. A., and Knight, R. (2012). Comparative metagenomic, phylogenetic and physiological analyses of soil microbial communities across nitrogen gradients. ISME J. 6, 1007-1017. doi: 10.1038/ismej.2011.159

Fierer, N., Strickland, M. S., Liptzin, D., Bradford, M. A., and Cleveland, C. C. (2009). Global patterns in belowground communities. Ecol. Lett. 12, 1238-1249. doi: 10.1111/j.1461-0248.2009.01360.x

Fritze, H., Perkiömäki, J., Saarela, U., Katainene, R., Tikka, P., Yrjälä, K., et al. (2000). Effect of Cd-containing wood ash on the microflora of coniferous forest humus. FEMS Microbiol. Ecol. 32, 43-51. doi: 10.1111/j.1574-6941.2000. tb00697.x

Frøslev, T. G., Kjøller, R., Bruun, H. H., Ejrnæs, R., Brunbjerg, A. K., Pietroni, C., et al. (2017). Algorithm for post-clustering curation of DNA amplicon data yields reliable biodiversity estimates. Nat. Commun. 8:1188. doi: 10.1038/ s41467-017-01312-x

Ho, A., Di Lonardo, D. P., and Bodelier, P. L. E. (2017). Revisiting life strategy concepts in environmental microbial ecology. FEMS Microbiol. Ecol. 93:fix006. doi: $10.1093 /$ femsec

Huotari, N., Tillman-Sutela, E., Moilanen, M., and Laiho, R. (2015). Recycling of ash - For the good of the environment? For. Ecol. Manage. 348, 226-240. doi: 10.1016/j.foreco.2015.03.008

Ihrmark, K., Bödeker, I. T. M., Cruz-Martinez, K., Friberg, H., Kubartova, A., Schenck, J., et al. (2012). New primers to amplify the fungal ITS2 regionevaluation by 454 -sequencing of artificial and natural communities. FEMS Microbiol. Ecol. 82, 666-677. doi: 10.1111/j.1574-6941.2012.01437.x

Insam, H., Knapp, B. A., Plank, R., and Von Holzasche, W. (2009). Use of wood ash and anaerobic sludge for grassland fertilization: Effects on plants and microbes. Die Bodenkultur 60, 39-51.

Jacobson, S. (2003). Addition of stabilized wood ashes to Swedish coniferous stands on mineral soils - Effects on stem growth and needle nutrient concentrations. Silva Fenn. 37, 437-450.

Johansen, J. L., Nielsen, M. L., Vestergård, M., Mortensen, L. H., Cruz-Paredes, C., Rønn, R., et al. (2021). The complexity of wood ash fertilization disentangled: effects on soil $\mathrm{pH}$, nutrient status, plant growth and cadmium accumulation. Environ. Exp. Bot. 185:104424. doi: 10.1016/j.envexpbot.2021.104424

Kiers, E. T., Duhamel, M., Beesetty, Y., Mensah, J. A., Franken, O., Verbruggen, E., et al. (2011). Reciprocal rewards stabilize cooperation in the mycorrhizal symbiosis. Science 333, 880-882. doi: 10.1126/science.1208473

Kjøller, R., Cruz-Paredes, C., and Clemmensen, K. E. (2017). "Ectomycorrhizal fungal responses to forest liming and wood ash addition: review and metaanalysis" in Soil Biological Communities and Ecosystem Resilience. eds M. Lukac, P. Grenni, and M. Gamboni (Denmark: Copenhagen University). 223-252. doi: 10.1007/978-3-319-63336-7_14

Kļaviņa, D., Muižnieks, I., Gaitnieks, T., Nikolajeva, V., Lazdiņa, D., Lazdiņš, A., et al. (2016). Fungal communities in roots of scots pine and Norway spruce saplings grown for 10 years on peat soils fertilized with wood ash. Balt. For. 22, 25-33. doi: $10.2307 / 2983152$

Klavina, D., Pennanen, T., Gaitnieks, T., Velmala, S., Lazdins, A., Lazdina, D., et al. (2015). The ectomycorrhizal community of conifer stands on peat soils 12 years after fertilization with wood ash. Mycorrhiza 26, 153-160. doi: 10.1007/s00572015-0655-2

Knapp, B. A., and Insam, H. (2011). Recycling of Biomass Ashes. Germany: Springer. $1-16$.
Kõljalg, U., Larsson, K. H., Abarenkov, K., Nilsson, R. H., Alexander, I. J., Eberhardt, U., et al. (2005). UNITE: A database providing web-based methods for the molecular identification of ectomycorrhizal fungi. New Phytol. 166, 1063-1068. doi: 10.1111/j.1469-8137.2005.01376.x

Lauber, C. L., Hamady, M., Knight, R., and Fierer, N. (2009). Pyrosequencing-based assessment of soil $\mathrm{pH}$ as a predictor of soil bacterial community structure at the continental scale. Appl. Environ. Microbiol. 75, 5111-5120. doi: 10.1128/AEM. 00335-09

Leifheit, E. F., Veresoglou, S. D., Lehmann, A., Morris, E. K., and Rillig, M. C. (2014). Multiple factors influence the role of arbuscular mycorrhizal fungi in soil aggregation-a meta-analysis. Plant Soil 374, 523-537. doi: 10.1007/ s11104-013-1899-2

Lilleskov, E. A., Kuyper, T. W., Bidartondo, M. I., and Hobbie, E. A. (2019). Atmospheric nitrogen deposition impacts on the structure and function of forest mycorrhizal communities: a review. Environ. Pollut. 246, 148-162. doi: 10.1016/j.envpol.2018.11.074

Mahmood, S., Finlay, R. D., Fransson, A.-M., and Wallander, H. (2003). Effects of hardened wood ash on microbial activity, plant growth and nutrient uptake by ectomycorrhizal spruce seedlings. FEMS Microbiol. Ecol. 43, 121-131. doi: 10.1111/j.1574-6941.2003.tb01051.x

Maresca, A., Hyks, J., and Astrup, T. F. (2017). Recirculation of biomass ashes to forest soils: ash composition, mineralogy and leaching properties. Waste Manag. 70, 127-138. doi: 10.1016/j.wasman.2017.09.008

Martin, M. (2011). Cutadapt removes adapter sequences from high-throughput sequencing reads. EMBnet J. 17, 10-12. doi: 10.14806/ej.17.1.200

Martinez Arbizu, P. (2020). pairwiseAdonis: Pairwise Multilevel Comparison Using Adonis. R Package Version 0.4. Available online at: https://github.com/ pmartinezarbizu/pairwiseAdonis.

Moore, D., Robson, G., and Trinci, A. (2011). 21st Century Guidebook to Fungi. Cambridge, NY: Cambridge University Press.

Mortensen, L. H., Cruz-Paredes, C., Qin, J., Rønn, R., and Vestergård, M. (2020). Effect of ash application on the decomposer food web and $\mathrm{N}$ mineralization in a Norway spruce plantation. Sci. Total Environ. 715:136793. doi: 10.1016/j. scitotenv.2020.136793

Nevarez, L., Vasseur, V., Le Madec, A., Le Bras, M. A., Coroller, L., Leguérinel, I., et al. (2009). Physiological traits of Penicillium glabrum strain LCP 08.5568, a filamentous fungus isolated from bottled aromatised mineral water. Int. J. Food Microbiol. 130, 166-171. doi: 10.1016/j.ijfoodmicro.2009.01.013

Nguyen, N. H., Song, Z., Bates, S. T., Branco, S., Tedersoo, L., Menke, J., et al. (2016). FUNGuild: an open annotation tool for parsing fungal community datasets by ecological guild. Fungal Ecol. 20, 241-248. doi: 10.1016/j.funeco. 2015.06.006

Oksanen, J., Blanchet, F. G., Kindt, R., Legendre, P., Minchin, O. 'H., et al. (2015). vegan: community Ecology Package. Available online at: http://cran.r-project. org/package=vegan (accessed February 2021).

Perkiömäki, J., and Fritze, H. (2002). Short and long-term effects of wood ash on the boreal forest humus microbial community. Soil Biol. Biochem. 34, 1343-1353. doi: 10.1016/S0038-0717(02)00079-2

Põlme, S., Abarenkov, K., Nilsson, R. H., Lindahl, B. D., and Engelbrecht, K. (2021). FungalTraits: a User-friendly Traits Database of Fungi and Fungus-like Stramenopiles. Minneapolis: University of Minnesota.

R Core Team (2020). R: a Language and Environment for Statistical Computing. Available online at: http://www.r-project.org/ (accessed February 2021).

Rognes, T., Flouri, T., Nichols, B., Quince, C., and Mahé, F. (2016). VSEARCH: a versatile open source tool for metagenomics. Peer 4:e2584. doi: 10.7717/peerj. 2584

Rousk, J., Bååth, E., Brookes, P. C., Lauber, C. L., Lozupone, C. A., Caporaso, J. G., et al. (2010). Soil bacterial and fungal communities across a $\mathrm{pH}$ gradient in an arable soil. Isme J. 4, 1340-1351. doi: 10.1038/ismej.2010.58

Rousk, J., Brookes, P. C., and Bååth, E. (2009). Contrasting soil pH effects on fungal and bacterial growth suggest functional redundancy in carbon mineralization. Appl. Environ. Microbiol. 75, 1589-1596. doi: 10.1128/AEM.02775-08

Rousk, J., Brookes, P. C., and Bååth, E. (2011). Fungal and bacterial growth responses to $\mathrm{N}$ fertilization and $\mathrm{pH}$ in the 150-year "Park Grass" UK grassland experiment. FEMS Microbiol. Ecol. 76, 89-99. doi: 10.1111/j.1574-6941.2010. 01032.x

Smith, S., and Read, D. (2008). Mycorrhizal symbiosis, 3rd Edn. London: Elsevier Ltd. 
Strickland, M. S., and Rousk, J. (2010). Considering fungal:bacterial dominance in soils - Methods, controls, and ecosystem implications. Soil Biol. Biochem. 42, 1385-1395. doi: 10.1016/j.soilbio.2010.05.007

Taylor, A. F. S., and Finlay, R. D. (2003). Effects of liming and ash application on below ground ectomycorrhizal community structure in two Norway spruce forests. Water, Air, Soil Pollut. Focus 3, 63-76. doi: 10.1023/A:1024171329124

Tedersoo, L., Bahram, M., Polme, S., Koljalg, U., Yorou, S., Wardle, D. A., et al. (2014). Global diversity and geography of soil fungi. Science 346, 1052-1053. doi: $10.1126 /$ science.aaa1185

van Der Heijden, M. G. A., Bardgett, R. D., and van Straalen, N. M. (2008). The unseen majority: soil microbes as drivers of plant diversity and productivity in terrestrial ecosystems. Ecol. Lett. 11, 296-310. doi: 10.1111/j.1461-0248.2007. 01139.x

Vestergård, M., Bang-Aandreasen, T., Buss, S. M., Cruz-Paredes, C., Bentzon-Tilia, S., Ekelund, F., et al. (2018). The relative importance of the bacterial pathway and soil inorganic nitrogen increase across an extreme wood ash application gradient. Glob. Chang. Biol. Bioenergy 10, 320-334. doi: 10.1111/gcbb.12494

Wheeler, K. A., Hurdman, B. F., and Pitt, J. I. (1991). Influence of pH on the growth of some toxigenic species of Aspergillus, Penicillium and Fusarium. Int. J. Food Microbiol. 12, 141-149. doi: 10.1016/0168-1605(91)90063-U

White, T. J., Bruns, T., Lee, S., and Taylor, J. (1990). "Amplification and direct sequencing of fungal ribosomal RNA Genes for phylogenetics" in PCR Protocols: a Guide to Methods and Applications. ed. M. Innis (San Diego: Academic Press). 315-322.
Whitman, W. B., Coleman, D. C., and Wiebe, W. J. (1998). Prokaryotes: the unseen majority. Proc. Natl. Acad. Sci. U. S. A. 95, 6578-6583. doi: 10.1073/pnas.95.12. 6578

Zimmermann, S., and Frey, B. (2002). Soil respiration and microbial properties in an acid forest soil: effects of wood ash. Soil Biol. Biochem. 34, 1727-1737. doi: 10.1016/S0038-0717(02)00160-8

Conflict of Interest: The authors declare that the research was conducted in the absence of any commercial or financial relationships that could be construed as a potential conflict of interest.

Publisher's Note: All claims expressed in this article are solely those of the authors and do not necessarily represent those of their affiliated organizations, or those of the publisher, the editors and the reviewers. Any product that may be evaluated in this article, or claim that may be made by its manufacturer, is not guaranteed or endorsed by the publisher.

Copyright (C) 2021 Cruz-Paredes, Bang-Andreasen, Christensen, Ekelund, Frøslev, Jacobsen, Johansen, Mortensen, Rønn, Vestergård and Kjøller. This is an open-access article distributed under the terms of the Creative Commons Attribution License (CC BY). The use, distribution or reproduction in other forums is permitted, provided the original author(s) and the copyright owner(s) are credited and that the original publication in this journal is cited, in accordance with accepted academic practice. No use, distribution or reproduction is permitted which does not comply with these terms. 